\title{
Antimicrobial Activity of Nisin, Reuterin, and the Lactoperoxidase System on Listeria monocytogenes and Staphylococcus aureus in Cuajada, a Semisolid Dairy Product Manufactured in Spain
}

\author{
J. L. Arqués, E. Rodríguez, M. Nuñez, and M. Medina ${ }^{1}$ \\ Departamento de Tecnología de Alimentos, INIA (Instituto Nacional de Investigación y Tecnología Agraria y Alimentaria), \\ Carretera de La Coruña km 7, 28040-Madrid, Spain
}

\section{ABSTRACT}

The inhibitory activity of nisin $(\mathrm{N})$, reuterin $(\mathrm{R})$, and the lactoperoxidase system (LPS), added individually or in combination, against Listeria monocytogenes and Staphylococcus aureus was investigated in "cuajada" (curdled milk), a semisolid dairy product manufactured in Spain. Cuajada was manufactured from UHT skim milk separately inoculated with $L$. monocytogenes and Staph. aureus, each at approximately $4 \log \mathrm{cfu} / \mathrm{mL}$, and held under conditions of temperature abuse $\left(10^{\circ} \mathrm{C}\right)$. On $\mathrm{d} 3$, a synergistic bactericidal activity was observed for the combinations of biopreservatives assayed, with $L$. monocytogenes counts of only $0.30 \mathrm{log} \mathrm{cfu} / \mathrm{mL}$ in cuajada made with $\mathrm{N}+\mathrm{R}+$ LPS vs. $8.31 \mathrm{log} \mathrm{cfu} / \mathrm{mL}$ in control cuajada. After $12 \mathrm{~d}$, L. monocytogenes could not be detected in cuajada made with added N + LPS or N $+\mathrm{R}$ + LPS. Staphylococcus aureus was more resistant than L. monocytogenes to biopreservatives added individually. On d 3, the synergistic effect of the 3 biopreservatives against Staph. aureus resulted in counts of 3.03 $\log \mathrm{cfu} / \mathrm{mL}$ in cuajada made with $\mathrm{N}+\mathrm{R}+$ LPS vs. 6.40 in control cuajada. After $12 \mathrm{~d}$, Staph. aureus counts were $2.61 \log \mathrm{cfu} / \mathrm{mL}$ in cuajada made with $\mathrm{N}+\mathrm{R}+$ LPS, whereas they ranged from 6.11 to $7.70 \mathrm{log} \mathrm{cfu} /$ $\mathrm{mL}$ in control cuajada and in cuajada made with other combinations of biopreservatives. The most pronounced decrease in pathogen counts was achieved by the triple combination $\mathrm{N}+\mathrm{R}+\mathrm{LPS}$, which acted synergistically on the inactivation of L. monocytogenes and Staph. aureus in cuajada over $12 \mathrm{~d}$ at $10^{\circ} \mathrm{C}$. The treatment combining these 3 natural biopreservatives at low concentrations, within the hurdle concept of food preservation, might be a useful tool to control the growth of pathogenic microorganisms in nonacidified dairy products.

Received February 21, 2007.

Accepted October 7, 2007.

${ }^{1}$ Corresponding author: mmedina@inia.es
Key words: nisin, reuterin, lactoperoxidase system, foodborne pathogen

\section{INTRODUCTION}

"Cuajada" is a traditional semisolid dairy product made in northern Spain from heat-treated ewe's or cow's milk. It is manufactured from pasteurized or UHT milk coagulated with rennet and stored below $8^{\circ} \mathrm{C}$, with a shelf life of 20 or $28 \mathrm{~d}$, respectively.

Listeria monocytogenes and Staphylococcus aureus are pathogens of great concern for the dairy industry. Listeria monocytogenes causes disease in high-risk groups, including pregnant women, neonates, and immunocompromised adults, and has a high mortality rate. Listeria monocytogenes is ubiquitous and can survive for long periods under adverse conditions. It is commonly found in dairy processing environments (Jeong and Frank, 1994) and can grow in refrigerated milk (Walker et al., 1990). Staphylococcus aureus is a major causative agent of bovine mastitis (Jablonski and Bohach, 2001), capable of producing enterotoxins responsible for one of the most prevalent causes of gastroenteritis. Cheese manufacture from raw milk has led to staphylococcal outbreaks (De Buyser et al., 2001). In addition, Staph. aureus may contaminate heat-treated milk during the manufacture of dairy products under inadequate hygiene conditions.

Consumer demands have led to renewed interest in the use of natural antimicrobials for food products. In the hurdle concept of food preservation, the combination of these biopreservatives to achieve an enhanced level of product safety and stability has gained increased attention. Nisin, a bacteriocin produced by some Lactococcus lactis strains, is commonly used as a biopreservative in the dairy industry and has a wide inhibitory spectrum against gram-positive bacteria, including L. monocytogenes and Staph. aureus. Nevertheless, the emergence of nisin-resistant bacteria at subinhibitory concentrations in sensitive gram-positive foodborne pathogens such as $L$. monocytogenes (Ming and Daeschel, 1993) would compromise its efficacy in 
food preservation. Reuterin ( $\beta$-hydroxypropionaldehyde) is a broad-spectrum antimicrobial compound produced by some strains of Lactobacillus reuteri during the anaerobic fermentation of glycerol (Axelsson et al., 1989). Reuterin is water soluble, active at a wide range of $\mathrm{pH}$ values, and resistant to proteolytic and lipolytic enzymes (El-Ziney et al., 1999). The bactericidal activity of reuterin against $L$. monocytogenes and Escherichia coli $\mathrm{O} 157: \mathrm{H} 7$ in milk and cottage cheese has been reported (El-Ziney and Debevere, 1998). The lactoperoxidase-thiocyanate-hydrogen peroxide system (LPS) occurs naturally in milk and exhibits antimicrobial activity against gram-positive and gram-negative bacteria (Kussendrager and van Hooijdank, 2000). The bactericidal effects of the LPS against $L$. monocytogenes (Earnshaw and Banks, 1989; Gaya et al., 1991) and Staph. aureus (Kamau et al., 1990) have been reported, although bacteriostatic activity on Listeria spp. followed by regrowth has also been described (Bibi and Bachmann, 1990). The antimicrobial activity of the LPS depends on environmental conditions, target strains, temperature, substrate, and mode of hydrogen peroxide generation (Wolfson and Sumner, 1993).

The aim of the present work was to evaluate the antimicrobial ability of combinations of nisin, reuterin, and the LPS as natural biopreservatives against L. monocytogenes and Staph. aureus in cuajada stored under conditions of moderate temperature abuse, which may serve as a model system for refrigerated nonacidified dairy products.

\section{MATERIALS AND METHODS}

\section{Bacterial Strains and Culture Conditions}

Listeria monocytogenes Scott A (from R. G. Crawford, Food and Drug Administration, Cincinnati, $\mathrm{OH}$ ) and Staph. aureus CECT 976 (Spanish Type Culture Collection) were used as test organisms. They were grown on tryptic soy broth (TSB; Biolife s.r.l., Milano, Italy) at $37^{\circ} \mathrm{C}$ for $18 \mathrm{~h}$. Clostridium tyrobutyricum NZ 8 (Nizo Food Research, Ede, the Netherlands) was grown in reinforced clostridial medium (Difco Laboratories, Sparks, MD) at $37^{\circ} \mathrm{C}$ for $48 \mathrm{~h}$ in anaerobic conditions and used as the indicator organism of nisin activity. Escherichia coli K12 (CECT 433) was grown in TSB at $37^{\circ} \mathrm{C}$ for $18 \mathrm{~h}$ and used as the indicator organism of reuterin activity. Bacterial strains were maintained as stock cultures at $-80^{\circ} \mathrm{C}$ in TSB supplemented with $15 \%$ glycerol (reinforced clostridial medium supplemented with $15 \%$ glycerol in the case of $C$. tyrobutyricum). They were propagated twice before use in experiments.

\section{Chemicals}

Stock solutions of nisin (Nisaplin, Aplin and Barret, Dorset, UK) were prepared in $0.02 \mathrm{~N} \mathrm{HCl}$ at a concentration of $10^{4} \mathrm{IU} / \mathrm{mL}$ and stored at $-40^{\circ} \mathrm{C}$. The nisin stock was diluted prior to use in experiments. Reuterin stock was obtained from $L b$. reuteri PRO 137 as previously described (Arqués et al., 2004a), lyophilized, stored at $-40^{\circ} \mathrm{C}$, and resuspended in sterile water before addition to milk. Lactoperoxidase from bovine milk (Sigma, St. Louis, MO) was prepared in distilled-deionized water to $5 \mathrm{mg} / \mathrm{mL}$ and stored at $-40^{\circ} \mathrm{C}$. Sodium thiocyanate (Merck, Darmstadt, Germany) was prepared in a $100 \mathrm{~m} M$ aqueous solution and sterilized. Hydrogen peroxide $30 \%$ (wt/wt) aqueous solution was obtained from Fluka (Buchs, Switzerland).

\section{Combined Effect of Nisin, Reuterin, and the LPS Against Gram-Positive Pathogens in Cuajada}

Cuajada was made from UHT skim milk with $0.04 \%$ fat (Pascual, Aranda de Duero, Spain) in duplicate experiments carried out on different days. In each experiment, either L. monocytogenes Scott A or Staph. aureus CECT 976 was inoculated at approximately $10^{4} \mathrm{cfu} / \mathrm{mL}$ into screw-capped flasks containing $200 \mathrm{~mL}$ of skim milk supplemented with 5\% skim milk powder and $0.02 \% \mathrm{CaCl}_{2}$ at $30^{\circ} \mathrm{C}$. The flasks were then distributed in 8 groups according to added biopreservatives: control cuajada, without biopreservatives; nisin; reuterin; LPS; nisin and reuterin; nisin and LPS; reuterin and LPS; and nisin, reuterin, and LPS. Nisin was added at 100 IU/mL. Reuterin was added at 2 arbitrary units (AU)/ $\mathrm{mL}$. The LPS was activated by adding lactoperoxidase to reach an estimated final activity of $0.22,2^{\prime}$-azinobis(3-ethylbenzthiazoline-6-sulfonic acid units (ABTSU)/mL. Aqueous solutions of $150 \mu \mathrm{L}$ of sodium thiocyanate and $150 \mu \mathrm{L}$ of hydrogen peroxide were then incorporated consecutively. After addition of rennet (0.015 g/L, Maxiren 150, Gist-Brocades, Delft, the Netherlands), milk from each flask was distributed into four $50-\mathrm{mL}$ sterile containers and held at $30^{\circ} \mathrm{C}$ for $40 \mathrm{~min}$. Cuajadas were stored under temperature abuse conditions, at $10^{\circ} \mathrm{C}$ for $12 \mathrm{~d}$.

\section{Microbiological and Chemical Analyses}

Cuajada was sampled in duplicate at $\mathrm{d} 0$ (inoculated control, without biopreservatives), 3, 6, 9, and 12. Listeria monocytogenes counts were determined on duplicate plates of PALCAM Listeria Selective Agar (Merck) with PALCAM Listeria Selective Supplement (Merck) after incubation at $37^{\circ} \mathrm{C}$ for $48 \mathrm{~h}$. Staphylococcus aureus was enumerated on duplicate plates of Baird-Parker agar (Oxoid Ltd., Basingstoke, UK) supplemented with egg 
yolk-tellurite solution (Difco Laboratories, Detroit, MI) after incubation at $37^{\circ} \mathrm{C}$ for $48 \mathrm{~h}$.

Nisin activity was determined as previously described (Rodríguez et al., 2005), with C. tyrobutyricum as the indicator organism. Inhibitory activity of purified reuterin extracts was determined by the modified assay of Chung et al. (1989) using $E$. coli K12 as the indicator strain (Arqués et al., 2004a). Reuterin AU were defined as the reciprocal of the greatest 2 -fold dilution that did not allow the growth of the indicator strain. The presence of reuterin in cuajada was estimated by dehydration to acrolein according to the method of Smiley and Sobolov (1962). The absorbance of the colored fractions containing reuterin was determined as described by Circle et al. (1945) at $490 \mathrm{~nm}$ in a Beckman DU 650 spectrophotometer (Beckman Instruments Inc., Fullerton, CA). Lactoperoxidase activity was measured prior to addition to milk according to the method of Marshall et al. (1986) and expressed in ABTSU according to Shindler et al. (1976).

\section{Statistical Analysis}

Data were subjected to ANOVA with the SPSS program Win, version 9.0 (SPSS Inc., Chicago, IL). The significance of differences between means for the same storage time was assessed by Tukey's test with a significance level of $\alpha=0.01$, using the same program.

\section{RESULTS}

\section{Inhibitory Activity of Nisin, Reuterin, the LPS, and Their Combinations on L. monocytogenes}

Levels of $L$. monocytogenes in cuajada were significantly $(P<0.001)$ influenced by the biopreservatives added and the days of storage at $10^{\circ} \mathrm{C}$, according to ANOVA results. Inhibitory activities of nisin, reuterin, and the LPS added individually or in combination on L. monocytogenes counts are shown in Table 1.

The L. monocytogenes count in inoculated control cuajada without biopreservatives at $0 \mathrm{~h}$ was $3.82 \mathrm{log} \mathrm{cfu} /$ $\mathrm{mL}$. Nisin and the LPS, added individually, caused a delay in the growth of the pathogen, with respective counts 2.74 and $4.12 \log \mathrm{cfu} / \mathrm{mL}$ lower after $3 \mathrm{~d}$ at $10^{\circ} \mathrm{C}$ than in control cuajada. However, the extension of the lag phase was followed by the growth of $L$. monocytogenes from d 3 to 9 up to levels similar to those found in control cuajada. No inhibitory activity of reuterin was detected, with $L$. monocytogenes counts in cuajada with reuterin similar to those found in control cuajada throughout the $12 \mathrm{~d}$ of refrigerated storage.

Listeria monocytogenes could not be detected on d 12 in cuajada with nisin in combination with the LPS. After $3 \mathrm{~d}$ at $10^{\circ} \mathrm{C}$, cuajada with nisin and LPS already showed counts $7.96 \log \mathrm{cfu} / \mathrm{mL}$ lower than control cuajada. This reduction was synergistic, because the combined effect of the 2 treatments $(7.96 \mathrm{log} \mathrm{cfu} / \mathrm{mL}$ ) was greater than the sum of individual reductions achieved on $\mathrm{d} 3$ by nisin (2.54 log cfu/mL) and the LPS (4.12 log $\mathrm{cfu} / \mathrm{mL}$ ). A similar bactericidal effect was attained on $\mathrm{d} 3$ with the combination of the 3 biopreservatives ( 8.01 $\log \mathrm{cfu} / \mathrm{mL}$ reduction) assayed. The pathogen could not be detected after $9 \mathrm{~d}$ in cuajada with nisin, reuterin, and the LPS. On $d 3$, reuterin in combination with the LPS also showed a bactericidal synergistic effect (5.25 $\log \mathrm{cfu} / \mathrm{mL}$ reduction) greater than the sum of the reductions achieved individually by reuterin (0.08 log cfu/ $\mathrm{mL}$ ) and the LPS (4.12 log cfu/mL). Growth of L. monocytogenes in cuajada with reuterin and LPS was recorded from d 3 onward, attaining levels similar to those in control cuajada on d 12 . The combination of nisin and reuterin showed a bacteriostatic effect on $L$. monocytogenes, which was synergistic with respect to the effects of individual preservatives and which restrained the growth of the pathogen during the first $6 \mathrm{~d}$ of storage.

\section{Inhibitory Activity of Nisin, Reuterin, the LPS, and Their Combinations on Staph. aureus}

Results of ANOVA revealed a significant $(P<0.001)$ influence of the biopreservatives added and the days of storage on Staph. aureus levels in cuajada. Results of the effects of nisin, reuterin, the LPS, and their combinations over $12 \mathrm{~d}$ of refrigeration at $10^{\circ} \mathrm{C}$ are shown in Table 2.

Counts of Staph. aureus in control cuajada without biopreservatives at $0 \mathrm{~h}$ were $3.77 \mathrm{log} \mathrm{cfu} / \mathrm{mL}$. After 3 $\mathrm{d}$, individually added biopreservatives led to a slight delay in the growth of the pathogen, although no statistically significant differences were observed with respect to levels in control cuajada. A similar behavior of Staph. aureus was recorded throughout the refrigeration period, with levels ranging from 6.48 to $7.52 \mathrm{log}$ $\mathrm{cfu} / \mathrm{mL}$ in cuajada with individual biopreservatives and of $7.70 \log \mathrm{cfu} / \mathrm{mL}$ in control cuajada after $12 \mathrm{~d}$ at $10^{\circ} \mathrm{C}$.

Combinations of 2 biopreservatives resulted in a greater inhibitory effect on Staph. aureus than when applied individually, with mean counts after $3 \mathrm{~d}$ ranging from $3.19 \mathrm{log} \mathrm{cfu} / \mathrm{mL}$ in cuajada with nisin and LPS to $3.87 \mathrm{log} \mathrm{cfu} / \mathrm{mL}$ in cuajada with nisin and reuterin compared with $6.40 \log \mathrm{cfu} / \mathrm{mL}$ in control cuajada. On d 3, significantly lower $(P<0.01)$ counts of Staph. aureus were obtained only in cuajada with nisin and LPS compared with those in control cuajada. Afterward, abundant bacterial growth resulted in Staph. aureus levels that did not differ significantly from those in control cuajada after $12 \mathrm{~d}$ of storage. 
Table 1. Listeria monocytogenes Scott A counts (log cfu/mL, mean $\pm \mathrm{SD})$ in cuajada made without biopreservatives $(\mathrm{C})$, or with nisin $(\mathrm{N})$, reuterin $(\mathrm{R})$, the lactoperoxidase system (LPS), or their combinations $(\mathrm{N}+\mathrm{R}$; $\mathrm{N}+$ LPS; $\mathrm{R}+$ LPS; $\mathrm{N}+\mathrm{R}+$ LPS) during storage at $10^{\circ} \mathrm{C}^{1}$

\begin{tabular}{lcccc}
\hline Treatment & $3 \mathrm{~d}$ & $6 \mathrm{~d}$ & $9 \mathrm{~d}$ & $12 \mathrm{~d}$ \\
\hline $\mathrm{C}$ & $8.31 \pm 0.65^{\mathrm{e}}$ & $8.77 \pm 0.06^{\mathrm{e}}$ & $8.81 \pm 0.06^{\mathrm{b}}$ & $8.53 \pm 0.04^{\mathrm{d}}$ \\
$\mathrm{N}$ & $5.77 \pm 0.45^{\mathrm{d}}$ & $8.05 \pm 0.05^{\mathrm{d}}$ & $8.30 \pm 0.06^{\mathrm{b}}$ & $8.05 \pm 0.04^{\mathrm{bc}}$ \\
$\mathrm{R}$ & $8.23 \pm 0.60^{\mathrm{e}}$ & $8.56 \pm 0.07^{\mathrm{e}}$ & $8.34 \pm 0.13^{\mathrm{b}}$ & $8.55 \pm 0.10^{\mathrm{d}}$ \\
$\mathrm{LPS}$ & $4.19 \pm 0.94^{\mathrm{bc}}$ & $7.92 \pm 0.10^{\mathrm{d}}$ & $8.37 \pm 0.10^{\mathrm{b}}$ & $8.47 \pm 0.02^{\mathrm{d}}$ \\
$\mathrm{N}+\mathrm{R}$ & $4.62 \pm 0.10^{\mathrm{cd}}$ & $6.79 \pm 0.02^{\mathrm{c}}$ & $8.20 \pm 0.11^{\mathrm{b}}$ & $7.90 \pm 0.05^{\mathrm{b}}$ \\
$\mathrm{N}+$ LPS & $0.35 \pm 0.49^{\mathrm{a}}$ & $0.24 \pm 0.33^{\mathrm{a}}$ & $0.30 \pm 1.17^{\mathrm{a}}$ & $\mathrm{ND}^{\mathrm{a}, 2}$ \\
$\mathrm{R}+$ LPS & $3.06 \pm 0.63^{\mathrm{b}}$ & $5.69 \pm 0.45^{\mathrm{b}}$ & $7.96 \pm 0.18^{\mathrm{b}}$ & $8.27 \pm 0.11^{\mathrm{cd}}$ \\
$\mathrm{N}+\mathrm{R}+$ LPS & $0.30 \pm 0.42^{\mathrm{a}}$ & $0.30 \pm 0.35^{\mathrm{a}}$ & $\mathrm{ND}^{\mathrm{a}}$ & $\mathrm{ND}^{\mathrm{a}}$ \\
\hline
\end{tabular}

${ }^{\mathrm{a}-\mathrm{e}}$ Values in the same column with different superscripts indicate differences $(P<0.01)$ between treatments for a given time.

${ }^{1}$ Initial count $(0 \mathrm{~h})$ in inoculated control cuajada was $3.82 \log \mathrm{cfu} / \mathrm{mL}$.

${ }^{2} \mathrm{ND}=$ below the detection limit $(1 \mathrm{cfu} / \mathrm{mL})$.

Nisin, reuterin, and the LPS in combination exhibited a longer lasting bacteriostatic effect on Staph. aureus in cuajada, with levels $5.09 \log \mathrm{cfu} / \mathrm{mL}$ lower than in control cuajada after $12 \mathrm{~d}$ at $10^{\circ} \mathrm{C}$, and $1.16 \log \mathrm{cfu} / \mathrm{mL}$ lower than those of control cuajada at $0 \mathrm{~h}$. This combined antibacterial activity could be considered to be synergistic, because the reduction attained with respect to counts in control cuajada on d $12(5.09 \log \mathrm{cfu} / \mathrm{mL})$ was greater than the sum of the individual effects achieved by nisin $(1.22 \mathrm{log} \mathrm{cfu} / \mathrm{mL})$, reuterin $(0.53 \mathrm{log}$ $\mathrm{cfu} / \mathrm{mL})$, and the LPS (0.18 $\log \mathrm{cfu} / \mathrm{mL})$.

\section{Nisin Activity and Reuterin Detection}

Nisin activity was detected throughout the refrigeration period in all samples to which it had been added. The diameters of the inhibition zones in plates with $C$. tyrobutyricum NZ8 as an indicator organism ranged from 16.5 to $18.1 \mathrm{~mm}$ (data not shown) during the 12 $\mathrm{d}$ of refrigerated storage. Apparently, the residual activity of nisin in cuajada was not affected by addition of the other preservatives.
The presence of reuterin (estimated as acrolein) in cuajada was observed throughout the refrigeration period in the samples to which this biopreservative had been added. Mean values of absorbance at $490 \mathrm{~nm}$ in cuajada with reuterin declined from 0.29 on $\mathrm{d} 3$ to 0.21 on d 12 , indicating a decrease in reuterin concentration as storage progressed (data not shown). This decrease might be ascribed to interactions with milk components, which needs to be confirmed with further research.

\section{DISCUSSION}

The inhibitory effect of nisin against $L$. monocytogenes in cuajada stored at $10^{\circ} \mathrm{C}$ was low. Previous results (Zapico et al., 1998) showed that growth of the pathogen at $30^{\circ} \mathrm{C}$ in milk with nisin added at $100 \mathrm{IU} /$ $\mathrm{mL}$ was resumed after an initial decrease lasting approximately $3 \mathrm{~h}$. The bacteriostatic activity of the LPS against $L$. monocytogenes detected in the present work agrees with the effect reported in milk by Kamau et al. (1990). However, a bactericidal effect of the LPS on this

Table 2. Staphylococcus aureus CECT 976 counts (log cfu/mL, mean \pm SD) in cuajada made without biopreservatives $(\mathrm{C})$, or with nisin $(\mathrm{N})$, reuterin $(\mathrm{R})$, the lactoperoxidase system (LPS), or their combinations $\left(\mathrm{N}+\mathrm{R} ; \mathrm{N}+\mathrm{LPS} ; \mathrm{R}+\mathrm{LPS} ; \mathrm{N}+\mathrm{R}+\right.$ LPS) during storage at $10^{\circ} \mathrm{C}^{1}$

\begin{tabular}{lllll}
\hline Treatment & $3 \mathrm{~d}$ & $6 \mathrm{~d}$ & $9 \mathrm{~d}$ & $12 \mathrm{~d}$ \\
\hline $\mathrm{C}$ & $6.40 \pm 1.77^{\mathrm{b}}$ & $7.44 \pm 1.42^{\mathrm{d}}$ & $8.04 \pm 1.06^{\mathrm{c}}$ & $7.70 \pm 0.88^{\mathrm{b}}$ \\
$\mathrm{N}$ & $5.12 \pm 1.42^{\mathrm{ab}}$ & $5.60 \pm 1.07^{\mathrm{bcd}}$ & $6.68 \pm 0.88^{\mathrm{bc}}$ & $6.48 \pm 0.74^{\mathrm{b}}$ \\
$\mathrm{R}$ & $5.49 \pm 1.82^{\mathrm{ab}}$ & $7.44 \pm 1.36^{\mathrm{d}}$ & $7.61 \pm 1.18^{\mathrm{bc}}$ & $7.17 \pm 0.67^{\mathrm{b}}$ \\
$\mathrm{LPS}$ & $5.38 \pm 0.80^{\mathrm{ab}}$ & $7.06 \pm 1.22^{\mathrm{cd}}$ & $7.81 \pm 0.73^{\mathrm{c}}$ & $7.52 \pm 0.71^{\mathrm{b}}$ \\
$\mathrm{N}+\mathrm{R}$ & $3.87 \pm 1.48^{\mathrm{ab}}$ & $6.09 \pm 0.53^{\mathrm{bcd}}$ & $7.17 \pm 1.21^{\mathrm{bc}}$ & $7.06 \pm 0.81^{\mathrm{b}}$ \\
$\mathrm{N}+$ LPS & $3.19 \pm 0.04^{\mathrm{a}}$ & $4.43 \pm 0.11^{\mathrm{ab}}$ & $5.36 \pm 0.16^{\mathrm{b}}$ & $6.26 \pm 0.40^{\mathrm{b}}$ \\
$\mathrm{R}+$ LPS & $3.70 \pm 0.89^{\mathrm{ab}}$ & $5.24 \pm 0.10^{\mathrm{abc}}$ & $6.32 \pm 1.53^{\mathrm{bc}}$ & $6.11 \pm 2.51^{\mathrm{b}}$ \\
$\mathrm{N}+$ R + LPS & $3.03 \pm 0.49^{\mathrm{a}}$ & $3.31 \pm 0.16^{\mathrm{a}}$ & $2.76 \pm 0.19^{\mathrm{a}}$ & $2.61 \pm 0.05^{\mathrm{a}}$ \\
\hline
\end{tabular}

${ }^{\mathrm{a}-\mathrm{d}}$ Values in the same column with different superscripts indicate differences $(P<0.01)$ between treatments for a given time.

${ }^{1}$ Initial count $(0 \mathrm{~h})$ in inoculated control cuajada was $3.77 \mathrm{log} \mathrm{cfu} / \mathrm{mL}$. 
microorganism in raw milk refrigerated at 4 and $8^{\circ} \mathrm{C}$ has also been described (Gaya et al., 1991; Rodríguez et al., 1997). Reuterin added to milk at $8 \mathrm{AU} / \mathrm{mL}$ exhibited a bacteriostatic effect on $L$. monocytogenes in milk at $37^{\circ} \mathrm{C}$, with no regrowth of the pathogen in treated milk observed after $24 \mathrm{~h}$ (Arqués et al., 2004a). Listeria monocytogenes was completely inactivated within $5 \mathrm{~d}$ at $7^{\circ} \mathrm{C}$ in milk with reuterin at $150 \mathrm{AU} / \mathrm{mL}$ (El Ziney and Debevere, 1998). According to these authors, the inactivation rate was dependent on reuterin concentration. In addition, Rasch et al. (2007) observed that the percentage of dividing Listeria innocua cells decreased with increasing concentrations of reuterin. The lack of antimicrobial activity of reuterin by itself observed in the present work could be due to the low concentration (2 AU/mL) of reuterin added.

Individual treatments showed a reduced inhibitory activity against Staph. aureus in cuajada over $12 \mathrm{~d}$ at $10^{\circ} \mathrm{C}$. However, nisin was bactericidal against Staph. aureus in milk at $37^{\circ} \mathrm{C}$ over $4 \mathrm{~h}$, although the pathogen resumed growth thereafter, reaching counts similar to those in control milk after $24 \mathrm{~h}$ (Arqués et al., 2004a). In cheese made from raw milk with a nisin-producing starter culture, a slight inhibitory effect of the bacteriocin on Staph. aureus was described (Rodríguez et al., 2000), whereas nisin added to white pickled cheese did not inhibit the pathogen (Abdalla et al., 1993). The LPS inhibited Staph. aureus growth in milk over $6 \mathrm{~h}$ at $37^{\circ} \mathrm{C}$, but the effect was lost after $24 \mathrm{~h}$ (McLay et al., 2002). In milk at $37^{\circ} \mathrm{C}$, a slight bactericidal effect on Staph. aureus of reuterin added at $8 \mathrm{AU} / \mathrm{mL}$ was reported by Arqués et al. (2004b), with 24 -h counts being 0.86 log $\mathrm{cfu} / \mathrm{mL}$ lower than those of 0 -h control milk and 5.53 $\log \mathrm{cfu} / \mathrm{mL}$ lower than those of 24 -h control milk. The low effectiveness of reuterin against Staph. aureus observed in the present work could be related to the low reuterin concentration used, as indicated for L. monocytogenes.

Combinations of biopreservatives resulted in greater inhibitory effects on L. monocytogenes and Staph. aureus in cuajada than when applied individually. A strong synergistic effect was attained with nisin in combination with the LPS and with the combination of the 3 biopreservatives, which resulted in L. monocytogenes levels below the detection limit on d 12. Staphylococcus aureus did not grow in cuajada with nisin, reuterin, and the LPS, reaching levels lower than in inoculated control cuajada after $12 \mathrm{~d}$ at $10^{\circ} \mathrm{C}$.

Thomas et al. (2000) reported that the combinations of nisin with chelators, nonionic and amphoteric surfactants, emulsifiers, lysozyme, other bacteriocins, and the LPS enhance the effect of the bacteriocin, whereas oxidizers, certain proteases, divalent cations, strong anionic detergents, and other bacteriocins reduce its anti- microbial activity. Addition of nisin and the LPS to milk showed a synergistic antimicrobial activity on $L$. monocytogenes at $30^{\circ} \mathrm{C}$ that was enhanced when the 2 biopreservatives were added in 2 steps with a time interval (Zapico et al., 1998). This synergistic effect was also found in milk maintained at $25^{\circ} \mathrm{C}$ for $15 \mathrm{~d}$ (Boussouel et al., 2000).

Few studies have been published on the combination of reuterin with other biopreservatives. The antimicrobial effect of reuterin on $L$. monocytogenes was enhanced by the addition of 3\% salt (El-Ziney and Debevere, 1998). In addition, a synergistic effect of reuterin in combination with lactic acid during meat decontamination has been reported (El-Ziney et al., 1999). In milk at $37^{\circ} \mathrm{C}$, Arqués et al. (2004a) detected a synergistic effect on L. monocytogenes and Staph. aureus when reuterin $(8 \mathrm{AU} / \mathrm{mL})$ was combined with nisin (100 IU/ $\mathrm{mL}$ ).

Although the mechanism of inactivation by the combination of the 3 treatments is not known, the primary target of nisin and the LPS is the cytoplasmic membrane. Nisin binds lipid II, inhibiting cell wall synthesis and forming pores in the membrane (Kramer et al., 2004). Antimicrobial action of the LPS is based on the oxidation of - $\mathrm{SH}$ groups of enzymes and other proteins, also leading to structural damage of microbial cytoplasmatic membranes (Kussendrager and van Hooijdank, 2000). This increase in membrane permeability might facilitate the antimicrobial action of reuterin, which inhibits ribonucleotide reductase and thioredoxin activities (Vollenweider and Lacroix, 2004) and thereby the synthesis of DNA.

Our results confirm that the synergistic antimicrobial effect between nisin and the LPS on L. monocytogenes observed at higher temperatures persists at refrigeration temperatures. It is also important to note that the application of nisin, reuterin, and the LPS in combination showed the greatest rate of inactivation on the 2 pathogens tested, achieving reductions to levels well below those considered to be harmful for consumers, even under refrigeration conditions of temperature abuse.

\section{CONCLUSIONS}

A synergistic bactericidal activity of nisin in combination with the LPS against $L$. monocytogenes was observed in cuajada stored for $12 \mathrm{~d}$ at $10^{\circ} \mathrm{C}$ under temperature abuse conditions. Counts of $L$. monocytogenes were reduced from initial values of $4 \mathrm{log} \mathrm{cfu} / \mathrm{mL}$ to levels below detection limits in cuajada made with nisin, reuterin, and the LPS on d 9 and in cuajada made with nisin and the LPS on d 12. A synergistic antimicrobial effect on Staph. aureus was detected when nisin was 
combined with reuterin and the LPS, resulting in counts $5 \log \mathrm{cfu} / \mathrm{mL}$ lower than in control cuajada after $12 \mathrm{~d}$ at $10^{\circ} \mathrm{C}$. The treatment combining these 3 natural biopreservatives at low concentrations, within the hurdle concept of food preservation, might be a useful tool to control the growth of pathogens such as L. monocytogenes and Staph. aureus, which might have access to milk used for the manufacture of dairy products through postpasteurization contamination.

\section{ACKNOWLEDGMENTS}

This work was supported by projects SC99-014 and AGL2000-0727-C03-03.

\section{REFERENCES}

Abdalla, O. M., P. M. Davidson, and G. L. Christen. 1993. Survival of selected pathogenic bacteria in white pickled cheese made with lactic acid bacteria or antimicrobials. J. Food Prot. 56:972-976.

Arqués, J. L., J. Fernández, P. Gaya, M. Nuñez, E. Rodríguez, and M. Medina. 2004a. Antimicrobial activity of reuterin in combination with nisin against food-borne pathogens in milk. Int. J. Food Microbiol. 95:225-229.

Arqués, J. L., M. Nuñez, M. Medina, and E. Rodríguez. 2004b. Synergistic effect of reuterin in combination with nisin on Staphylococcus aureus in milk. Milchwissenschaft 59:373-375.

Axelsson, L. T., T. C. Chung, W. J. Dobrogosz, and S. E. Lindgren. 1989. Production of a broad spectrum antimicrobial substance by Lactobacillus reuteri. Microb. Ecol. Health Dis. 2:131-136.

Bibi, W., and M. R. Bachmann. 1990. Antibacterial effect of the lactoperoxidase-thiocyanate-hydrogen peroxide system on the growth of Listeria spp. in skim milk. Milchwissenschaft 45:26-28.

Boussouel, N., F. Mathieu, A. M. Revol-Junelles, and J. B. Millière. 2000. Effects of combination of lactoperoxidase system and nisin on the behaviour of Listeria monocytogenes ATCC 15313 in skim milk. Int. J. Food Microbiol. 61:169-175.

Chung, T. C., L. T. Axelsson, S. E. Lindgren, and W. J. Dobrogosz. 1989. In vitro studies of reuterin synthesis by Lactobacillus reuteri. Microb. Ecol. Health Dis. 2:137-144.

Circle, S. J., L. Stone, and C. S. Boruff. 1945. Acrolein determination by means of tryptophane. Ind. Eng. Chem. Anal. Ed. 17:259-262.

De Buyser, M. L., B. Dufour, M. Maire, and V. Lafarge. 2001. Implication of milk and milk products in food-borne diseases in France and in different industrialised countries. Int. J. Food Microbiol. 67:1-17.

Earnshaw, R. G., and J. G. Banks. 1989. A note on the inhibition of Listeria monocytogenes NTCC 11994 in milk by an activated lactoperoxidase system. Lett. Appl. Microbiol. 8:203-205.

El-Ziney, M. G., and J. M. Debevere. 1998. The effect of reuterin on Listeria monocytogenes and Escherichia coli $\mathrm{O} 157: \mathrm{H} 7$ in milk and cottage cheese. J. Food Prot. 61:1275-1280.

El-Ziney, M. G., T. van den Tempel, J. Debevere, and M. Jakobsen. 1999. Application of reuterin produced by Lactobacillus reuteri 12002 for meat decontamination and preservation. J. Food Prot. 62:257-261.

Gaya, P., M. Medina, and M. Nuñez. 1991. Effect of the lactoperoxidase system on Listeria monocytogenes behavior in raw milk at refrigeration temperatures. Appl. Environ. Microbiol. 57:33553360 .
Jablonski, L. M., and G. A. Bohach. 2001. Staphylococcus aureus. Pages 411-434 in Food Microbiology: Fundamentals and Frontiers. 2nd ed. M. P. Doyle, L. R. Beuchat, and T. J. Montville, ed. ASM Press, Washington, DC.

Jeong, D. K., and J. F. Frank. 1994. Growth of Listeria monocytogenes at $10^{\circ} \mathrm{C}$ in biofilms with microorganisms isolated from meat and dairy processing environments. J. Food Prot. 57:576-586.

Kamau, D. N., S. Doores, and K. M. Pruitt. 1990. Antibacterial activity of the lactoperoxidase system against Listeria monocytogenes and Staphylococcus aureus in milk. J. Food Prot. 53:1010-1014.

Kramer, N. E., E. J. Smid, J. Kok, B. de Kruijff, O. P. Kuipers, and E. Breukink. 2004. Resistance of Gram-positive bacteria to nisin is not determined by Lipid II levels. FEMS Microbiol. Lett. 239:157-161.

Kussendrager, K. D., and A. C. M. van Hooijdank. 2000. Lactoperoxidase: Physico-chemical properties, occurrence, mechanism of action and applications. Br. J. Nutr. 84(Suppl. 1):19-25.

Marshall, V. M. E., W. M. Cole, and A. J. Bramley. 1986. Influence of lactoperoxidase system on susceptibility of the udder to Streptococcus uberis infection. J. Dairy Res. 53:507-514.

McLay, J. C., M. J. Kennedy, A. L. O'Rourke, R. M. Elliot, and R. S. Simmonds. 2002. Inhibition of bacterial foodborne pathogens by the lactoperoxidase system in combination with monolaurin. Int. J. Food Microbiol. 73:1-9.

Ming, X., and M. A. Daeschel. 1993. Nisin resistance of foodborne bacteria and the specific resistance responses of Listeria monocytogenes Scott A. J. Food Prot. 56:944-948.

Rasch, M., A. Métris, J. Baranyi, and B. Bjørn Budde. 2007. The effect of reuterin on the lag time of single cells of Listeria innocua grown on a solid agar surface at different $\mathrm{pH}$ and $\mathrm{NaCl}$ concentrations. Int. J. Food Microbiol. 113:35-40.

Rodríguez, E., J. L. Arqués, P. Gaya, J. Tomillo, M. Nuñez, and M. Medina. 2000. Behaviour of Staphylococcus aureus in semi-hard cheese made from raw milk with a nisin-producing starter. Milchwissenschaft 55:633-635.

Rodríguez, E., J. L. Arqués, M. Nuñez, P. Gaya, and M. Medina. 2005. Combined effect of high-pressure treatments and bacteriocin-producing lactic acid bacteria on inactivation of Escherichia coli $\mathrm{O} 157: \mathrm{H} 7$ in raw-milk cheese. Appl. Environ. Microbiol. 71:3399-3404.

Rodríguez, E., J. Tomillo, M. Nuñez, and M. Medina. 1997. Combined effect of bacteriocin-producing lactic acid bacteria and lactoperoxidase system activation on Listeria monocytogenes in refrigerated raw milk. J. Appl. Microbiol. 83:389-395.

Shindler, J. S., R. E. Childs, and W. G. Bardsley. 1976. Peroxidase from human cervical mucus. Eur. J. Biochem. 65:325-331.

Smiley, K. L., and M. Sobolov. 1962. A cobamine-requiring glycerol dehydrase from an acrolein-forming Lactobacillus. Arch. Biochem. Biophys. 97:538-543.

Thomas, L. V., M. R. Clarkson, and J. Delves-Broughton. 2000. Nisin. Pages 463-524 in Natural Food Antimicrobial Systems. A. S. Naidu, ed. CRC Press, Boca Raton, FL.

Vollenweider, S., and C. Lacroix. 2004. 3-Hydroxypropionaldehyde: Applications and perspectives of biotechnological production. Appl. Microbiol. Biotechnol. 64:16-27.

Walker, S. J., P. Archer, and J. G. Banks. 1990. Growth of Listeria monocytogenes at refrigeration temperatures. J. Appl. Bacteriol. 68:157-162.

Wolfson, L. M., and S. S. Sumner. 1993. Antibacterial activity of the lactoperoxidase system: A review. J. Food Prot. 56:887-892.

Zapico, P., M. Medina, P. Gaya, and M. Nuñez. 1998. Synergistic effect of nisin and the lactoperoxidase system on Listeria monocytogenes in skim milk. Int. J. Food Microbiol. 40:35-42. 